\section{CONSUMPTION AND CONSUMER SOCIETY AS POSTMODERNITY IN CONTEMPORARY THAI FICTION}

\section{Saowanit Chunlawong ${ }^{1}$}

\begin{abstract}
This article aims to scrutinize the postmodern concept of consumption and consumer society from the Thai perspective through four Thai short stories written in a period exemplary of economic change including "Hong Thoe Hong Chan Khan Kan Duai Khwam Ngao" (Your Room, My Room Separated by Loneliness), by Paritat Hutangkul; "Pathanukrom Chiwit Chabap Khon Chan Klang Krungthep" (The lexicon of the life of middle class Bangkokians) and "Ching ming" (Tomb sweeping day), by Win Lyovarin; and "Lok Bai Lek Khong Salman" (The little world of Salman), by Kanogpong Songsompuntu. Each represents Thai society as a consumer society where people live between constant dilemma and vital agony. In these four stories, consumption is corrupt eroding social norms, moral values, and human dignity. Since consumption is an apparatus of the system of production, it perpetuates it by exploiting the individual's needs and desires. People cannot evade a perpetual rise in consumption, and are therefore bound to this socio-economic mode.
\end{abstract}

\footnotetext{
${ }^{1}$ Assistant Professor, Department of Thai, Faculty of Liberal Arts, Thammasat University
}

\section{Introduction}

Thai fiction is generally assumed to be a reflection of Thai society while Thai writers are perceived as undertaking the burden of social critics. For this reason, a lot of Thai fiction puts an emphasis on class struggle, and represents stories of characters whose lives are problematic, affected by such social conditions. After 1986, Thai society has adjusted in accordance with the economic policies of the government. This change has affected people and their social patterns. Writers, as social critics, problematize these patterns through the means of representation in their works.

One of the problematic situations selected for representation is the dilemma of consumption in Thai society, though the meaning of this consumption is different from the classical concept of consumption, i.e. the object of all production with individuals maximizing their satisfaction through purchasing from an everexpanding range of goods. Baudrillard denied the explanation of the present phenomena of consumption and consumer society, or postmodernity, as affluence and luxury of objects, or purchasing and possessing goods. He argued that consumption is "a systematic act of the manipulation of signs" (Baudrillard 2001: 25). This definition illuminates the complexity of the postmodern concept of consumption. Baudrillard proposed this concept by integrating Saussure's theory of sign with Marx's theory of value in order to explain the phenomena of production and consumption in present times. 
This article aims to scrutinize the postmodern concept of consumption and consumer society from the Thai perspective through four Thai short stories including "Hong Thoe Hong Chan Khan Kan Duai Khwam Ngao" (Your Room, My Room Separated by Loneliness), "Pathanukrom Chiwit Chabap Khon Chan Klang Krungthep" (The lexicon of the life of middle class Bangkokians), "Ching ming" (Tomb sweeping day), and "Lok Bai Lek Khong Salman" (The little world of Salman). By exploring these works, the article attempts to elaborate upon the postmodern concept of consumption and consumer society concealed within the author's mode of story-telling.

\section{Baudrillard's concept of consumption and consumer society}

Jean Baudrillard is argubly a postmodern theorist. He invents several concepts to approach contemporary phenomena, such as, simulation, simulacra, and hyperreality. These concepts result from his argument on consumption and consumer society. To explain consumption in a contemporary society, Baudrillard surpasses Marxist theories of production, in favor of the Sausurrean theory of sign. He indicates that an individual characterizes consumption as a process of social identification (Lane 2000: 75-76).

Baudrillard (2001: 25) defined consumption as "a systematic act of the manipulation of signs". In this way, an object of consumption is transformed from signs by the system of production to the latter. The latter transgresses sign value, in stead of use value, into exchange value, by modifying the purchased object from economic exchange into symbolic exchange. Consumption is to consume the constructed sign value of objects. People purchase them because they indicate a social meaning and individual identity. In this way, consumption posits them into a social group. People are in turn subject to cultural codes, while purchasing objects. They are not as free as individuals in modern ideology. On the contrary, they are subject to society by means of objects.

In this case, consumption is based on the ideology of self-fulfillment. Since objects are designed to set social relations in people, they can respond to individuals' desire to achieve their social status by possessing those objects. To urge the need for self-fulfillment, the system of production construct consumer's need and desire. Thus, they are partially the system of production, which controls and assembles the system of consumption, in order to motivate people to consume products. People only appear to have chances to choose what they want. But they are indeed trapped in consumption.

In a consumer society, the system of production invents the system of consumption for the sake of the system of production itself, that is, the more consumption, the more production. To propel the system of production, consumption intervenes into individual's everyday life; it motivates him/her to seek convenience, pleasure and comfort; moreover, it drives his/her life to flow within a stream of products. As a result, pleasure is established. All consuming activities become increasingly located in a given place, such as a store. People are satisfied with this kind of environment 
decorated with objects. They live happily in the midst of products. Therefore, society is full of objects and services for consumers to pursue and waste. As Baudrillard puts it: "We reached the point where "consumption" has grasped the whole of life [...]." (Baudrillard 2001:36)

To reiterate Baudrillard's statement, consumption, in society, is an apparatus of the system of production. It is a procedure that propels the system of production. For this reason, the system of production exploits need and desire to reinforce consumption. It produces not only objects but also needs and desires attached to those objects. Consumption here reproduces the production. It makes the system of production expand and become a form that dominates gesture of human mentality, ethics, and everyday ideology.

\section{Consumption and consumer society from Thai perspectives}

Four Thai short stories analyzed in this article represent different perspectives toward consumption and consumer society. "Hong Thoe Hong Chan Khan Kan Duai Khwam Ngao" (Your Room, My Room Separated by Loneliness) and "Pathanukrom Chiwit Chabap Khon Chan Klang Krungthep" (The lexicon of the life of middle class Bangkokians) represent the theme that is the crisis of individuals in the everyday life in consumer society. "Ching ming" (Tomb sweeping day) explains consumption as a reinforcement of the system of production. Finally, "Lok Bai Lek Khong Salman" (The little world of Salman) reveals the dilemma of individuals who live as subjects of this consumer society. To represent these issues, the writers avoid telling stories along realist and socialist realist conventions to describe and critique the phenomena, and instead use different and alternate techniques to render stories that reflect a narrative complexity by representing the complicated situations instead of a mere reflection of society.

\section{The seduction of consumption}

"Hong Thoe Hong Chan Khan Kan Duai Khwam Ngao" (Your Room, My Room Separated by Loneliness) (2000), by Paritat Hutangkul, is the story of a man, the narrator, who was infatuated with an illusory girl until he almost lost his real life. The story contains the implication of consumption in terms of the protagonist and the illusory girl: "my eyes drank her figure thirstily" (Hutangkul 2000: 141), "my food is your spirit, your entrails and your blood. I'm gonna swallow you slowly, like a paub" (Hutangkul 2000: 148), "I've eaten you by your eyes, your breath, your spirit. I chewed slowly, ate slowly, here and there." (Hutangkul 2000: 150). Accordingly, the story can be seen as an allegory to individual's desire for consumption.

In consumer society, objects of consumption attract individuals by their own needs and desires. This inhibits individuals from restraining themselves from consuming. By consuming products, individuals choose to consume, while in fact, consumption is forced. They appeal leads their desires unconsciously until finally they are trapped within the

\footnotetext{
${ }^{2}$ Pop (ปอบ), a kind of ghost feeding on the entrails of a person it possesses
} 
seduction of consumption. Individuals do not realize that they are deluded. They feel that they gain power and have the chance to choose, and they can choose freely. Actually, they are merely in control of conditions or rules set by the system of consumption. Acclimatized to consuming, they are desensitized to the process of consuming, to an extent to which the need to consume ever more excessively expands. Consumption, subsequently, overwhelms the whole of the individuals' life. It has swallowed them unnoticeably, leaving only the symptom of "hysteria," which Baudrillard (2001: 48) explained as the effect of the relation between needs to consume and objects of consumption. Objects of consumption urge individuals' need and desire to consume. They make individuals consume uncontrollably. Yet they swallow them into the system of consumption.

In the story, the relationship between the protagonist and the illusory girl represents the seduction of consumption. The illusory girl seduces and overwhelms him by his own desire. Claiming that she was embodied from his lust, the illusory girl arouses him then to request him to make her real and flesh by his touch, after which she would consent to be his lover. In spite of three conditions, especially one that she would erode his spirit and entrails ${ }^{3}$, he accepts her offer.

His decision shows that he is mistaken. He thinks of himself as the master of the situation since he is the one who makes a decision. Actually, he is seduced at the

${ }^{3}$ The other two are: he had to keep her origin secret and he must not anger her. beginning. He cannot restrain his desire to approach the illusory girl because of his lust and his solitude in the environment of a lonely seaside bungalow. Later, he cannot stop his affair with his object of affection, to the extent that his desire to consume more of her eventually reaches its limit. He has to follow his desire instead of controlling himself. For a while, he has found that he lost his ability to distinguish colors. His spirit and entrails has been eroded. In spite of her confession, he can hardly distance himself from an embodied image of her.

The relationship between the protagonist and the illusory girl is the same as the relationship between consumers and consumption. It is reciprocal. The protagonist as the consumer is fascinated in fulfilling his desire by consuming the girl. He is not interested in the effect of the conditions the girl has set. While he enjoys patterns of consumption, the girl, the metaphor of consumption, consumes him in return for life. This vicious circle makes consumption strong and difficult to resist. However, the story still gives hope to deal with this seduction, that is, the protagonist, finally, can give up the relationship and realizes at the end that he would make use of desire, instead of submitting to it.

To present the story of an individual who indulges in consuming happiness, the author has parodied the Japanese tale, "Urashimataro," the story of Urashimataro, a young man who has helped a turtle and been rewarded by being taken to the underworld to live there with the princess. After three years, he remembers his mother and goes back home. He finds out that three hundred years have passed. $\mathrm{He}$ 
is so regretful that he breaks his promise to the princess. He opens her magic box. It makes him older and older. After that he cannot return to the underworld again. The same as the protagonist in "Hong Thoe Hong Chan Khan Kan Duai Khwam Ngao" (Your Room, My Room Separated by Loneliness), Urashimataro is so infatuated with happiness provided by the girl that he abandons his normal life. The seduction represented as a girl in both stories is significant. The personification shows the traditional gender bias and the sexual stereotype of binary opposition: A woman seduces a man and the man is the victim. By means of this sexual stereotype, the theme of being addicted to happiness with the girl in "Urashimataro" is developed to being addicted to consuming a girl for happiness in "Hong Thoe Hong Chan Khan Kan Duai Khwam Ngao" (Your Room, My Room Separated by Loneliness).

The difference between "Urashimataro" and "Hong Thoe Hong Chan Khan Kan Duai Khwam Ngao" (Your Room, My Room Separated by Loneliness) lies in the motif of the genre. "Urashimataro" as a tale is didactic. "Hong Thoe Hong Chan Khan Kan Duai Khwam Ngao" (Your Room, My Room Separated by Loneliness), is a short story which contains a critique of contemporary society. In spite of the magical elements i.e. the illusory girl feeding herself by eroding a man's spirit and entrails, the protagonist becoming color blind unreasonably, the story is not a just tale but a representation of consumer society's illusion. Living in the real world together with the magical world of the illusory girl represents the individual's life in illusions constructed and presented by the system of production. Driven by seeds of desire cultivated in his/her mind, an individual fulfills his/her pleasure by consuming objects of consumption as happiness is readily provided.

It can be said that the author is optimistic because he still believes in humanity. Finally, the protagonist can divorce himself from the girl. The ending of the story illustrates that the individual can reject consumption and emancipate himself from its seduction. This attitude is likely to be an ethical value inherited from the motif of the didactic tale, in which humanity is instructed to live consciously and evade all delusions wisely. However, this optimistic attitude of the relationship between individuals and consumption is not enough because it is too straightforward. The situation of consumer society is so complicated that individuals cannot get out of the circle of consumption easily. And "Pathanukrom Chiwit Chabap Khon Chan Klang Krungthep" (The lexicon of the life of middle class Bangkokians) has demonstrated this.

\section{The vicious circle of the system of consumption}

"Pathanukrom Chiwit Chabap Khon Chan Klang Krungthep" (The lexicon of the life of middle class Bangkokians) (1994), by Win Lyovarin, projects the ordinary life of the narrator, a middle-aged man, trapped in the vicious circle of consumption. His narrative of everyday life illustrates his dilemma within the pitfalls of consumption. His everyday life is narrated as a middle class individual who habitually consumes to the extent that conducts his life style in consumerism, 
since he is induced to believe that certain commodities are necessary for living a life in a particular social environment.

Here, the necessity of living a life like that is not only the four requisites: provisions, shelter, remedies and clothing, but also the luxuries that make life more comfortable, i.e., vehicles, credit cards, mobile phones, alarm clocks, and so forth. Furthermore, education, insurance, entertainment appear to be necessary for a secure and happy life. Subsequently, individuals are convinced that happiness, convenience and wealth are signs of middle class life. By using the encyclopedia form, the story represents the state of objects as signs, that is, objects consist of the signifier and the signified which is given by the protagonist, not initiated from the beginning. These definitions are not the actual meanings of the objects but show that they are signifiers of life style and wealth. And since commodities are transformed into signifiers that indicate social classes, individuals consume them to define and articulate their social status or social standing point.

To describe his everyday life, the protagonist follows his activities from morning to night and inserts some lexicons and their definition into the narrative, such as 'alarm clock,' 'car,' 'credit card,' 'cigarette,' 'stock market,' 'fast food,' etc. The definitions imply the network of commodities occupying everyday life. The daily life reveals that commodities and consumption take part in his life style. They push him to consume them and reinforce him in the circle of consumption.
The network of commodities is not natural but articulated, that is, the system of production offers commodities to individual as a series of more and more complex choices. Commodities are not scattered but classified. They are discontinuous but relatively integrated to each other, responding to individual's need and desire. In the story, commodities can be grouped as products necessary for daily life such as houses, schools, food, powdered milk, condoms, medicine, etc.; products for entertainment such as radio, karaoke, pubs, compact discs, video tapes, Japanese comics, cigarettes, and alcohol; products for financial convenience, such as credit cards, insurance, bank services and stock markets. These groups are related to each other through the life style of individual as the center of consumption. The first two groups are to respond to individual's need and desire, while the last group of products serves as consuming products for the previous.

In these groups, what is apparent is the duplication of commodities. Products of each group appear to be different but they also share. The pub, for example, is for relaxation similar to karaoke. Radios, compact discs, video tapes and Japanese comics seem to align themselves with a kind of home entertainment. Cigarettes and alcohol are for the same purpose. Credit cards, bank services, insurance and stock markets look like the same kind of financial services. Here, there are many kinds of products; each product can be separated into many sorts or brands as exemplary of chances and choices for consumers to choose. But it can be seen as profusion or accumulation that represents affluence and abundance responding to the middle class's feature of 
living life as a yuppie: "I also deserve a good life!” (Lyovarin 1994: 161)

The story indicates the pitfall of the consumer society as a vicious circle of the system of consumption. The system of production has established the system of consumption by exploiting the human need for freedom and independence which in turn induces individuals to consume. This need makes the individual feel easy and prone to purchase material products via financial services, such as, credit cards and loans by which they can buy on credit, pay in installments and need not have cash of their own in hand. With the easiness and convenience of consumption, individuals fall into the pitfall of the middle class ideology of a happy life, including a nice family, a proper house, a small car, a good job and an adequate salary. This life style is an end for an individual to achieve. His/her goal urges consumption. It brings him/her into a circle of life which individuals cannot escape from consumption, while living happily with commodities.

By means of starting and ending at the same situation in the morning of every day, the story expresses the repetition in everyday life of the protagonist in consumer society as routine. His life becomes unhappy and frustrated. $\mathrm{He}$ is tired and lifeless as a robot. But he still resists following the yuppie ideology and does not pursue false happiness. Contrary to him, his friend has enjoyed consuming. That means one can take advantage of consumption to live comfortably and happily in stead of being immersed in the predicament of consumption.
Whether or not pursuing happiness, each individual has to consume commodities provided by the system of production. A middle class individual is held within a vicious circle of the system of consumption and in the midst of commodities as signs. The lexicon of commodities placed in between the narrative reveals the state of commodities as the life style signifiers of the middle class. The process of transforming material products into signifiers begins when products lose their use value. This process is illustrated below in "Ching ming" (Tomb sweeping day).

\section{The fluidity and instability of values}

"Ching ming4" (Tomb sweeping day) (1999), another work of Win Lyovarin, presents the development of the economic mode via the monologue of the protagonist, the youngest generation of a Chinese business family. His reflections on each cousin marks a change in the mode of business affairs from selling and manufacturing to promoting goods as objects of consumption by way of market management, which is now the most prosperous business model in the economic circulation of the present day.

\footnotetext{
${ }^{4}$ Ching ming or Qingming (pure brightness) is the most important day of sacrifice. Chinese offer sacrifices to their ancestors at grave sites to pay remembrance and honor. Young and old sweep the tombs and offer food, tea, wine, and flowers, then burn incense and paper accessories, bow and pray before the memorial tablet.
} 
This change means the change of the system of production different from the past: the technical system, the system of investment and circulation, and the wagelabor force. The promotion of commodities can be manipulated by producing characteristics of objects appropriate to target consumers. In this case, entrepreneurs have to emphasize marketing, and then turn to invest more in market management and advertising instead of manufacturing. Thus, concrete labors in the system of production are substituted by technology. Intelligence becomes the dominant form of labor. The cost of products is not only the cost of manufacturing but also the cost of market management and advertising. Thus the very change resides in the change of the ideology of production. That is, production is not only to produce products but to produce the force of consumption.

The protagonist as the youngest generation disappoints his family by working as an employee in a marketing company instead of owning his own business similar to his relatives. His potential the company requires is not the actual labor but the intelligence which can produce more profit, such as his idea about the funeral:

All in this cemetery are substandard. It's sure that these grave sites were not designed by architects. If built with modern design, their prices could be $10-30 \%$ more than those of competitors who manage nothing. Moreover, the cost could be lower by building readily designed models. And they could be more attractive with more varied decoration. Aim at the affluent. People die only once.

(Lyovarin 1999: 255)
His job proposes the tendency of a new system of production where the important unit of the system is marketing. This unit performs the necessity and satisfaction of products by adding socio-cultural features that gives products value. Thus, the ceremonial value of accessories projected by market management means nothing related to the ceremony, but more to the image of the grateful descendants. The story implies the meaninglessness of gratefulness via the purpose of the protagonist who comes to join the Ching ming ceremony merely for his job rather than to express his gratefulness.

By connecting gratefulness to objects, the story reveals the process of object culturalization. Objects are transformed to cultural signifiers. The thought of developing products such as the candle, the ceremony, the grave site, the pavement in front of the gravestone, for example, sheds light on the fact that meanings and values can be reconstructed and redirected toward different targets; therefore they are fluid and instable. Parallel to the fluid, instable meaning, and value of objects of consumption, the story demonstrates the fluidity and instability in meaning and value of the Chinese identity in the conflict between the protagonist and his family. All of his relatives define themselves as Chinese. They maintain and express their Chinese identity in some customs and traditions. The most customary is that kinship that is at the heart of the matter which boils down to 'gratefulness'. On the contrary, the protagonist tries to wipe out all signifiers of Chinese identity such as name, family name, clothes, etc., and he does not come ever to join the ceremony on Ching ming day for many years, since the ceremony gives rise to complaints about his 
ungratefulness. The irony is, after getting rid of the signs of his Chinese bloodline, the protagonist himself accepts that his talent for business, portrayed by the story as a rigid Chinese identity, is inherited from his family.

By switching the present time with the past, the author reveals the fluidity and instability with regard to the value of being Chinese. He describes that the protagonist was insulted by the virtue of being Chinese when he was young but his experience with his Chinese business family is very useful in the present day, the period of capitalism. Chinese identity shifts from gratefulness to business capacity. Therefore, it can be said that neither gratefulness nor business capacity is the real Chinese identity. Both are signifiers of Chinese identity that can cause transitions through a shift in conditions.

Presenting the fluidity and instability of Chinese identity together with the changeable value of objects, the story confirms the signification that reconstructs the value of things and transforms things to signifiers of values. In an era where sign value comes together with cultural meaning, consumers consume cultural values to perform their identity and to compensate for a lack of cultural life. The system of production bends to mold cultural features into commodities in order to create selling points in the manner of the above protagonist. The question is what the societal attitude to this phenomenon is. "Lok Bai Lek Khong Salman" (The little world of Salman) is a short story that attacks this situation with the ambivalence by revealing the irony of seeking cultural values in commodities.

\section{The excessive symbolic exchange}

"Lok Bai Lek Khong Salman" (The little world of Salman) (1993), by Kanogpong Songsompuntu, tells the story of Salman who struggles against the expansion of hotel business by keeping his land and his local life instead of selling his only property and changing his way of life. The irony of fate is that his land and lodge become an important part of the hotel view and his local life turns out to be a fascinating commodity presented to the hotel's customers. This is exemplary of cultural commodification in the present consumer society.

In the present day, objects of consumption are culturalized to be different and distinct from others. By this process, the economic exchange value of objects shifts from use value to sign value (Baudrillard, 2001: 35). However, the story shows that Salman's land gains not only the economic exchange value but also the sign value of human dignity, which cannot be exchanged. For Salman, keeping his land is keeping his dignity. It is so valuable that it cannot be exchanged with money. But upon realization that he has become the spectacle for hotel customers, the excessive symbolic exchange is illustrated. $\mathrm{He}$ cannot maintain his dignity as he anticipated.

From the beginning, Salman's land is meant to be use value because it is his dwelling place. After refusing to sell his land to live there and continue his ordinary life, Salman has established sign value to his land. The land is not a place but the symbol of his dignity. It is priceless and invaluable. On the contrary, the hotel 
entrepreneur just wants this land for hotel construction because it is on the beach directly in front of the hotel. Later, the hotel owner changes the plan and exploits Salman's land as a symbol and enchantment for the hotel to lure customers.

The front of the hotel is a large patio with a swimming pool, embraced by three buildings. [...] Next forward, instead of the beach, is a ruined hut surrounded in coconut trees. [...] After morning came, seeing the faint thread of fog spreading over coconut trees with white smoke drifting over the roof and the local fishing boat trembled gently in small waves, I could not stand admiring the idea of the hotel owner. I believed that, when looking out of the hotel in the morning like this, all customers appreciated this view as beautiful as if it had been painted.

(Songsompuntu 1993: 60-61)

The image of Salman's way of life is very different from the urban life of customers who live comfortably with convenience and entertainment in the city. Salman's way of life is the so-called natural and local life represented by the hotel owner as a primitive way of life. In this way, Salman's way of life can respond well to the nostalgic feeling of urban consumers. This is why they choose this hotel: "I don't believe that. But I know what Lam said is true. He said half of the customers, especially foreigners, prefer Andaman Inn because they are impressed with the view of the little world of Salman" (Songsompuntu 1993: 69). The customers do not realize that the manner of local life they yearn for was destroyed by the hotel business and that they are part of this process by enjoyably consuming Salman's way of life.

Moreover, the narrator reveals the ambivalence of nostalgia when he depicts the hotel scene as a small town with a bar, a discotheque, a mini-theatre, a health club and a swimming pool. These places illustrate the contrast between the urban and local way of life, and declare the fact that the beach hotel is not different from the city residence if decorated as a natural park. Furthermore, the hyperreality of nature and local culture is similar to their residence in town. While seeking natural and local life, people do not really desire that way of life. They just want to appreciate it and leave it there outside of their path.

The story of Salman is extremely ironic. Salman, who establishes the sign value of his land, never gains profits. He is forced to live in a difficult way while the hotel entrepreneur gets all benefits and the customers live happily with the new cultural meaning of Salman living his life. The image of Salman's residency and life style become the hyperreality - a local fisherman which diminishes when hotels came. Salman tries to resist this signification and to maintain his human dignity by offering to sell his land to the hotel owner after he finds out that he was interesting and peculiar within the gaze of the hotel customers. However, the land is worthless. Its value is not the land itself but the life lived upon this land, Salman's life.

Trying to emancipate himself from the snare and refusing to be a 'human zoo,' 
Salman gives up fishing, the only means of his livelihood, to avoid being gazed at and photographed. He aggressively refuses a salary offered by the hotel owner for living his life as usual. Moreover, he forbids his family to accept money from customers who asks to take photograph with them, and even attacks customers who take photographs of him or his family. Parallel with Salman's story, is Lam, the hotel bartender who tells the narrator Salman's background. He sells his land and becomes an employee of the hotel. He is insulted but able to live his life, while Salman is trapped within the irony of rural life in a modern environment.

The narrator who witnesses to the dilemma of Salman, and of which he is a part of it, seems to be sorry for his agony and propagates his story as a work of art. But according to the conceptual framework of meta-fictional writing, it reveals the fact that Salman's life is still exploited. So, in an era of consumption and a society ruled by it, no one can escape its effects. The question remains whether to consume or to be consumed, or both.

\section{Conclusion}

These four short stories present Thai writers' perspectives toward contemporary Thai society, which affirm the phenomena of consumption in Thai society. That is, consumption penetrates into individual's life inevitably and affects his/her way of life.
In "Hong Thoe Hong Chan Khan Kan Duai Khwam Ngao" (Your Room, My Room Separated by Loneliness), the protagonist's pleasure and desire to consume arises as if it is embedded within his mind, and in "Pathanukrom Chiwit Chabap Khon Chan Klang Krungthep" (The lexicon of the life of middle class Bangkokians), need is raised to be the cause of consumption, while "Ching ming" (Tomb sweeping day) reveals that it is the system of production that manufactures needs and desires to perpetuate the circle of consumption. And while consumption erodes someone's life, many perform this erosion as enjoyment as in "Lok Bai Lek Khong Salman" (The little world of Salman).

The complexity of the narratives represents the complexity of the phenomena. The stories show that consumption is as magical as the illusory girl. The process is boring but fascinating. It makes people feel happy to consume, forcing people to live their daily life in a vicious circle repeatedly and again and again. People are overcome by the process of signification and culturalization. By means of consumption, they erode both themselves and others.

According to these pessimistic perspectives, consumption and consumer society place people within a dilemma of torment and bring them in perpetual dilemma with themselves. Pleasure and happiness are illusory and reduce human into the subject of consumption. The writers inscribe consumption and consumer society as evil, an erosion of the ethical value and the fundamental roots of society and people. People who are those caught within the vicious of consumption, 
or remain unaware of its process, are destined to adapt their lives in accord with the hyperreal development of their environment.

Nevertheless, all the stories imply that living in consumer society has to be and can be manipulated. People can take advantage of a chance to fulfill their life, such as Lam in "Lok Bai Lek Khong Salman" (The little world of Salman) and the protagonist's friend in "Pathanukrom Chiwit Chabap Khon Chan Klang Krungthep" (The lexicon of the life of middle class Bangkokians). They both seem to be criticized for submitting to consumption. But it is undeniable that they can continue their proper life any longer. The protagonist in "Ching ming" (Tomb sweeping day) is proposed as the example of one who appreciates the value of fundamentals. At the same time, the story shows that he chooses to take benefit from it. And it is the protagonist in "Hong Thoe Hong Chan Khan Kan Duai Khwam Ngao" (Your Room, My Room Separated by Loneliness) who shows the way to deal with consumption, that is, make fun of it.

In conclusion, in spite of realizing that consumption and consumer society are inevitable, each of the aforementioned writers hope that the individual can be spirited enough to restrain the desires evoked by the system of production to consume, and turn to a foundation envisioned as virtue. On the contrary, though there is a kind of tone in the stories insinuating that the world remains the same, which approach the consumerism phenomena as an interplay between living life and spending life in a circle of consumption.

\section{References}

Baudrillard, Jean. 2001. Jean Baudrillard: selected writings. $2^{\text {nd }}$ ed. Standford: Standford University Press.

Hutangkul, Paritat. 2000. "Hong Thoe Hong Chan Khan Kan Duai Khwam Ngao (Your Room, My Room Separated by Loneliness)." Maemot Bon Tuek (The witch in the building). Bangkok: Rupe Jan.

Lane, Richard J. 2000. Jean Baudrillard. New York: Routledge.

Lyovarin, Win. 1994. "Pathanukrom Chiwit Chabap Khon Chan Klang Krungthep (The lexicon of the life of middle class Bangkokians)." Aphet Kamsuan (The mourning of the odd). Bangkok: 113.

Lyovarin, Win. 1999. "Ching ming (Tomb sweeping day)." Sing Mi Chiwit Thi Riak Wa Khon (The being called human). $3^{\text {rd }}$ ed. Bangkok: Double Nine Printing.

Songsompuntu, Kanogpong. 1993. "Lok Bai Lek Khong Salman (The little world of Salman)." Saphan Khat (The torn bridge). $2^{\text {nd }}$ ed. Bangkok: Nok See Luaeng.

http://www.china.org.cn/english/features/ Festivals/78319.htm.

http://en.wikipedia.org/wiki/ Qingming_Festival. 